\title{
One-pot Synthesis of 2-seleno-4-methylquinoline
}

\author{
Tangali R. Ravikumar Naik, Halehatty S. Bhojya Naik *, S. Ramesh, M. Raghavendra and G. \\ Krishnamurthy
}

Department of Studies and Research in Industrial Chemistry, School of Chemical Sciences, Kuvempu University, Shankaraghatta-577 451, India

* Author to whom correspondence should be addressed. Fax: +91-08282-256255; E-mail: hsb naik@,rediffmail.com

Received: 17 December 2006 / Accepted: 3 January 2007 / Published: 2 June 2007

Keywords: Quinoline, DNA binding, antitumour, organoselenium

Number of workers has reported the synthesis of condensed fused quinoline derivatives containing selenium atom and studied for their DNA binding, cytotoxic, anticancer and antitumour activities [1-3]. The reported ring system of interest because of close relationship with anticancer alkaloid ellipticine [4]. Therefore, the development of organoselenium compounds with higher anticarcinogenic efficacy but better tolerance continues to be a priority in chemotherapy research. So, we have tentatively identified these 2-selenium-4-methylquinolines as new member of the class of antitumour drug and starting material for the synthesis of many tri- and tetra cyclic planar molecules. We herein report facile, eco-friendly and one-pot synthesis of 2-seleno-4-methylquinoline from 2-chloro-4-methylquinoline.

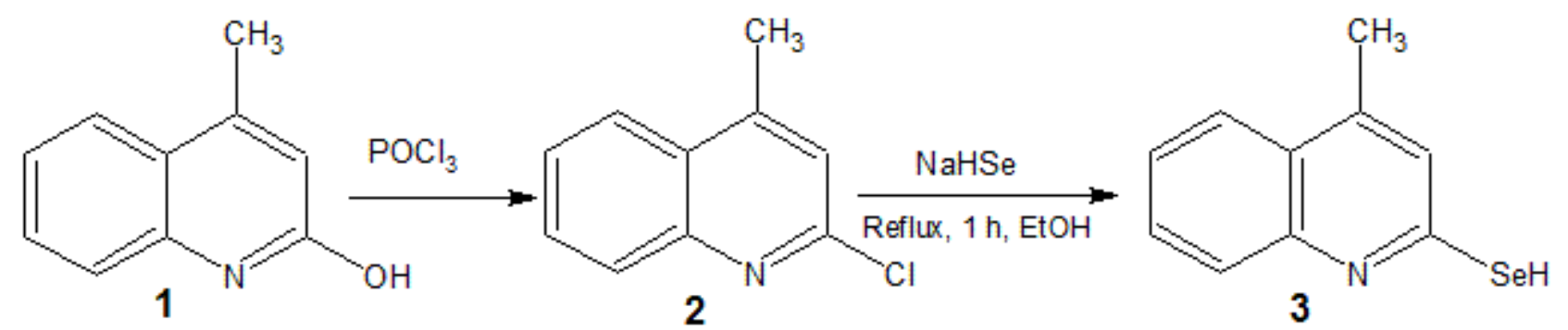

The synthesis of 2-hydroxy-4-methylquinoline and 2-chloro-4-methylquinoline were prepared according to literature procedure [5].

A mixture of 2-chloro-4-methylquinoline $2(1.58 \mathrm{~g}, 1 \mathrm{mmol})$ and NaHSe $(1 \mathrm{~g}, 1 \mathrm{mmol})$ was refluxed at $80-90{ }^{\circ} \mathrm{C}$ in presence of ethanol $(5 \mathrm{ml})$ for $1 \mathrm{~h}$. The completion of the reaction was monitored by TLC eluting the phase ethyl acetate: carbon tetrachloride $(80: 20)$. The reaction mixture was poured in to crushed ice $(25 \mathrm{gm})$. The product was filtered, washed with water, dried and was pure enough for further use. The obtained compound was characterised by elemental analysis, IR, ${ }^{1} \mathrm{H}$ NMR, ${ }^{13} \mathrm{C}$ NMR and mass spectral data. The 2-seleno-4-methylquinoline 3 has a yellow, solid powder, yield $80 \%$.

Melting Point: $170-173^{\circ \mathrm{C}}$

IR $\left(\mathrm{KBr}, \mathrm{cm}^{-1}\right)$ : n $1558(\mathrm{C}=\mathrm{N}) ; \mathrm{n} 1634(\mathrm{C}-\mathrm{SeH})$.

${ }^{1} \mathrm{H}-\mathrm{NMR}\left(\mathrm{CDCl}_{3}, 250 \mathrm{MHz}\right): \mathrm{d}=2.63\left(3 \mathrm{H}, \mathrm{s}, \mathrm{CH}_{3}\right), 6.38-7.28(5 \mathrm{H}, \mathrm{m}, \mathrm{Ar}), 10.8(1 \mathrm{H}, \mathrm{s}, \mathrm{SeH})$.

${ }^{13} \mathrm{C}-\mathrm{NMR}\left(\mathrm{CDCl}_{3}, 67.5 \mathrm{MHz}\right): \mathrm{d}=126.0,127.4,127.9,128.0,130.4,140.0,142.2,143.0,149.5,153.5$. 
Mass Spectra (relative intensity): $\mathrm{m} / \mathrm{z}\left(\mathrm{M}^{+2}\right)=222$

Elemental Analysis: Calculated for $\mathrm{C}_{10} \mathrm{H}_{9} \mathrm{NSe}: \mathrm{C}: 54.07, \mathrm{H}: 4.08, \mathrm{~N}: 6.31$, Se: 35.54 Found: C: 54.05 , H: 4.07, N: 6.29, Se: 35.52 .

\section{References}

1. Gopal, M.; Veeranna, S.; Doddamani, L.S. Spectroscopy Letters 2004, 37, 347.

2. Gopal, M.; Shahabuddin, M.S.; Inamdar, S.R. Indian Acad. Sci. (Chem. Sci). 2002, 114, 687.

3. Ravikumar Naik, T.R.; Bhojya Naik, H.S.; Raghavendra, M.; Gopalkrishna Naik, S.R. ARKIVOC 2006, $15,1$.

4. Frei, E.; Bieler, C.A.; Arlt, V.M.; Wiessler, M.; Stiborova, M. Biochem. Pharmacol. 2002, 64, 289.

5. Bhojya Naik, H.S.; Ramesh, S.; Swetha, B.V.; Roopa Phosphorus Sulfur Silicon Relat. Elem. 2006, $181,533$.

(C) 2007 by MDPI (http://www.mdpi.org/). Reproduction is permitted for noncommercial purposes. 